\title{
ГРАМАТИКА
}

УДК 811.161.2’367

С. М. Кривенко

\section{ТЕОРЕТИЧНІ ЗАСАДИ ВИВЧЕННЯ ПИТАЛЬНИХ РЕЧЕНЬ У КОНТЕКСТІ ПРОФЕСІЙНОЇ ДІЯЛЬНОСТІ}

У статті презентовано вивчення питальних речень у професійній діяльності, окреслено їхню роль як одного з важливих компонентів фахової успішності. Розглянуто функційно-семантичні особливості питальних речень, їхню специфіку як засобу професійної комунікаціі. Визначено ті питальні конструкиіï, що є найчастотнішими в різних типах дискурсу, зокрема медичному, публіиистичному, юридичному, військовому. Запропоновано класифікацією питальних речень, яка сприятиме ширшому витлумаченню комунікативних характеристик питальних речень у вимірах професійного мовлення.

Ключові слова: питальне речення, професійна компетенція, мовлення фахівия, професійний діалог, професійний дискурс, класифікація питальних речень.

Kryvenko S. Theoretical Principles of Studying Interrogative Sentences in the Context of Professional Activity. Today, professional activity of a specialist in any field requires grammatically correct written and oral speech, he or she must have a number of competencies: professional, emotional, communicative, linguistic. Language mediates professional communication, is a means of effective coordination, in particular with the help of interrogative sentences. This study will contribute to productive solution of special tasks, will serve as a basis for high-quality training of specialists. The article is aimed at generalizing functional-semantic and communicative-pragmatic characteristics of interrogative sentences and outlining the peculiarities of their use in professional discourses of different types. Achieving the aim involves solving the following tasks: 1) to determine the productivity of interrogative sentences in a professional sphere; 2) to outline theoretical foundations of the study of interrogative sentences in Ukrainian linguistics, approaches to their interpretation, typology; 3) to characterize functioning of interrogative sentences in different professional discourses; 4) to establish a correspondence between the functions of interrogative sentences and the peculiarities of professional activities of different types.

For an adequate analysis of interrogative sentences in professional activity of a specialist, interrogative sentences should be distinguished according to a number of criteria, in particular the type of a question, expected answer, communicative and 
functional focus. Professional speech always has a special purpose, hence an effective analysis of interrogative sentences is possible only if the structure of the corresponding discourse is taken into account. In medical discourse, it is, in particular, doctor's autocommunication, which determines the presence of a specific sphere of functioning of interrogative sentences; in journalism, it is a division into interviews, where self-interrogative sentences dominate, and a monologic presentation of information, where non-self-interrogative sentences predominate; in court, it is a special regulatory function of interrogative sentences accompanied by the ritual of discourse; in military radio broadcasting, it is a block structure that influences the role of interrogative sentences. Thorough study of all aspects of the functioning of interrogative sentences in professional activity will deepen the understanding of their nature, will help to clarify structure of communicative and language competencies, will allow effective language training of future specialists.

Key words: interrogative sentence, professional competence, speech of a specialist, professional dialogue, professional discourse, classification of interrogative sentences.

\section{Вступ}

Нині в професійній діяльності фахівця будь-якої галузі помітно зростає роль мови. До претендентів на вакантні посади працедавці разом з освітніми, технічними та інтелектуальними вимогами до умінь і навичок також висувають вимоги грамотного писемного та усного мовлення (Центр розвитку кар'єри КПІ імені Ігоря Сікорського. Дайджест актуальних вакансій). Ефективна професійна діяльність можлива лише за умови, коли фахівець володіє низкою компетенцій: професійною, емоційною, комунікативною, мовною. Як специфічна характеристика діяльності компетенція складається з елементів знань, умінь та навичок і виражається в поведінкових характеристиках, що безпосередньо пов'язані з критеріями ефективних і успішних дій у професійних та життєвих ситуаціях. Мова опосередковує професійну комунікацію, є засобом ефективної координації дій, зокрема з допомогою використання питальних речень.

Мета роботи - узагальнити функційно-семантичні та комунікативно-прагматичні характеристики питальних речень, окреслити особливості їх уживання в професійних дискурсах різного типу. Для досягнення мети розв'язуємо такі завдання: 1) визначити продуктивність питальних речень у професійній сфері; 2) окреслити теоретичні засади вивчення питальних речень в українському мовознавстві, 
підходи до їх трактування, типології; 3) схарактеризувати функціювання питальних речень у різних професійних дискурсах; 4) встановити відповідність між функціями питальних речень та особливостями професійної діяльності різних типів.

\section{Методи дослідження}

Для досягнення поставленої мети було використано загальнонаукові методи: аналізу й синтезу, спостереження та узагальнення для аналітичного опрацювання досліджень і публікацій, лінгвістичні методи: описовий - слугував для оприявнення, виокремлення специфіки питальності в різних професійних дискурсах, а також для окреслення різноманітних змістових відтінків думок, емоційно-експресивних особливостей питальних речень; зіставний - для визначення спільних і відмінних рис питальних речень різних типів у досліджуваних дискурсах; почасти метод дискурс-аналізу - для означення суб'єктивного, регламентованого рольового мовлення всіх суб’єктів професійної взаємодії.

\section{Виклад основного матеріалу}

Важливим механізмом взаємодії та узгодження спеціальної інформації є діалог. Вирішення ним позамовних завдань зумовлено метою самого процесу спілкування. Діалог уважають функційним різновидом мовлення, типом комунікації, принципом їі організації. Учасники діалогу під час його реалізації витворюють особливий тип тексту, що поєднує вербальний і невербальний компоненти, і має на меті вплинути на умови комунікації, дії ії учасників, зокрема їхню поведінку. Участь у діалозі передбачає можливість ставити найрізноманітніші питання і відповідати на них, зокрема реалізовувати інструментальну функцію, що полягає в розв'язанні професійних завдань. У цьому аспекті діалогічність має вирішальне значення.

Діалогічність зазвичай утілюється використанням цілої низки комунікативних ресурсів, словесних моделей: запитань - відповідей, запитань - перепитувань, запитань - стверджень, запитань - сумнівів, риторичних запитань тощо. Кожна з указаних моделей містить запит на інформацію. Крім того, певна модель може перебувати в основі композиції окремих частин діалогу або ж інтегрувати різні моделі, уміщуючи декілька запитів на інформацію. Типова реалізація 
інтерогативу - міжособистісної мовленнєвої взаємодії, спрямованої на запит інформації мовця до слухача - здійснюється за допомогою питальних речень різного типу.

Така різноплановість у вживанні питальних конструкцій природно має різне функційно-смислове тлумачення. Слушним $є$ твердження С. Шабат, що «питальне речення як своєрідна за формою, семантикою, комунікативною функцією та інтонацією синтаксична одиниця здатне відображати найбільш широку гаму об'єктивних та суб'єктивних значень» (Шабат, 2000: 5). Його граматична структура продиктована запитом на реалізацію згаданих значень і може вказувати на пошук інформації, iї з'ясування та уточнення, підтримування контакту, перевірки й активізації уваги співрозмовника, констатацію інформації, експлікацію експресивного ствердження чи заперечення; спонукання до дії та вираження бажання; репрезентації емоційного стану мовця та оцінки; висловлення внутрішніх переживань, роздумів. Вочевидь, запитання $€$ не тільки носієм змісту, формою існування особливої думки зі строго закріпленим значенням питальності, а й виразником емоційності, експресивності, численних прагматичних сенсів. Широкий спектр функцій питальних речень зумовив різні критерії їх типології: за емоційними відтінками (М. Івченко (Івченко, 1965)), за модальністю (А. Загнітко (Загнітко, 2009), О. Пазяк (Пономарів, 1997), С. Шабат (Шабат, 2000; Шабат, 2001)), за гносеологічним принципом (Л. Кадомцева (Білодід, 1969)) тощо.

Ірунтовне потрактування питальних конструкцій в українському мовознавстві репрезентовано в дисертаційній праці С. Шабат (Шабат, 2000), низці публікацій М. Панкової (Панкова, 2007; Панкова, 2009a; Панкова, 2009b). Окремі аспекти функціювання таких одиниць у контексті професійної комунікації розглянуто в монографічних дослідженнях Н. Литвиненко (Литвиненко, 2009b), I. Завальнюк (Завальнюк, 2009), розвідках Л. Пономарьової (Пономарьова, 2010а; Пономарьова, 2010b); Пономарьова, 2011), дослідженнях А. Просяної (Просяна, 2016а; Просяна, 2016b; Просяна, 2017; Просяна, 2018), О. Шаблія (Шаблій, 2015). У цих студіях питальні конструкції подано з погляду функційно-семантичної організації на комунікативно-прагматичному рівні. Комунікативні можливості питального речення як засобу професійного словесного вираження висвітлено з урахуванням різноманітних змістових відтінків думок, емоційно-експресивних 
особливостей повідомлень, ствердження чи заперечення інформації, спонукання співрозмовника до певної дії, вираження здивування, сумніву, оцінки тощо.

Комунікативна продуктивність питальних речень у фаховій сфері залежить від способів адресованості, типу професійної галузі. Комунікативний потенціал медичного діалогічного мовлення на прикладі автокомунікації як одного зі «способів лінгвістичної реалізації лікарем його прагматичних намірів під час діалогу з пацієнтом» докладно розглянуто в праці Н. Литвиненко (Литвиненко, 2009а). Особливістю цього різновиду мовленнєвої діяльності $є$ те, що адресатом повідомлення $є$ сам адресант. У системі розмаїтих контактів автокомунікація виявляє свою ефективність, оскільки нерідко професійна діяльність передбачає пошук інформації, іiі з'ясування та уточнення, підтримування контакту, отже, потребує ефективного використання питальних конструкцій. Для лікарської практики така самоадресація $€$ типовою. За спостереженням Н. Литвиненко, характер самоадресації може бути зумовлений «специфікою етапів, на яких відбувається <..> спілкування з пацієнтом. Це етапи знайомства, опитування, об’єктивного обстеження та етап рекомендацій» (Литвиненко, 2009а: 85). Отже, типи запитань можуть змінюватися. На основі дослідження автокомунікації встановлено такі регулярні питальні відтворення: загальнопитальні речення, що вживають на етапі знайомства 3 метою налагодження контакту, та фатичні речення, які використовують на етапі первинного опитування для виявлення скарг. 3 метою підтримання контакту, уточнення діагнозу лікар використовує перепитування, яке зазвичай має автокомунікативний характер. Порушене в праці питання автокомунікації в медичному дискурсі є одним із цілого комплексу актуальних проблем українського медичного дискурсу, простудійованих на монографічному рівні (Литвиненко, 2009b).

Достатньо повно опрацьована тема функціювання питальних речень в публіцистичному стилі, зокрема в мові газет (Завальнюк, 2009). Останні напрацювання в сучасному мовознавстві в аспекті функційно-стилістичних параметрів речень питальної модальності зумовили потребу переосмислення цієї проблеми. І. Завальнюк відзначила, що «власне-питальні речення за своїми експресивними можливостями й кількісним виявом в українській пресі початку XXI ст. поступаються місцем перед іншими структурами, оскільки найповніше 
виявляють себе лише в жанрі інтерв’ю, де, входячи до структури діалогічного мовлення реплікою стимулу, спонукають до відповідної реакції» (Завальнюк, 2009: 181). На думку дослідниці, такі речення здебільшого позбавлені виразної експресії, а в структурі діалогу вони спонукають до отримання конкретної інформації. Інші типи питальних речень мають інформаційну та емоційно-експресивну різноплановість. Виокремлено й проаналізовано особливості синтаксичних структур, що не мають власне-питальної специфіки, а виконують експресивно-стилістичну функцію (жанр міні-інтерв'ю в структурі авторського монологу), речення авторизовано-оцінного значення 3 виразним емоційно-оцінним значенням та високим ступенем експресії, питальні речення, що містять звернення до групового адресата, питальні речення зі вставними словами в їхньому складі, питальні речення в ролі структурних компонентів початків публікацій та передтекстів, використання питальних речень у ролі газетних заголовків тощо (Завальнюк, 2009).

Різні типи питальних речень з метою організації та виконання професійної діяльності функціюють і в мові юридичної сфери. Питальними конструкціями вона вписується в реальні узагальнені моделі дійсності, відображає впливи як мовного, так і позамовного характеру. Специфіку мови юридичних документів влучно схарактеризувала Р. Водак: «...формулювання як юридичних документів, так і політичних заяв, призначених для широкої публіки, є зрозумілими дуже вузькому колу людей, при цьому перифраз сприяє розумінню цих текстів для тих людей, які зрозуміли текст від початку і без перифразу» (цит. за: Карасик, 2002: 207). Утім питальні конструкції є лише частиною загальної комунікативної ситуації. Під час постановки питання зазвичай ураховується ціла низка чинників, зокрема й статусно-рольові, особистісні характеристики учасників комунікації, мета спілкування, узагальнені уявлення про типове місце перебігу фахової комунікації, прагматичне значення висловлювання. Звідси й різнотлумачення комунікантами одних і тих самих мовних повідомлень (Пономарьова, 2011). Відомості, виокремленні з них, можуть бути значно інформативніші за деякі мовні масиви, слугувати додатковим джерелом інформації. У юридичній сфері функційний аспект мови має досить неоднозначну специфіку. Вона полягає в позамовній дійсності, а саме в концептуалізації системи науки, зв'язків понять, що іiі 
структурують, оскільки юридична сфера поділяється на різноманітні галузі права - законодавчу, судову, адміністративну тощо. Кожна з указаних юридичних галузей як елемент системної ланки права пов'язана з комунікативною діяльністю, впливами на неї позамовних чинників. Питальні конструкції слугують тут важливим знаряддям розгляду тих чи тих компонентів процесуальних дій, ïх аргументації, стимулюють зміни в свідомості учасників комунікації.

Судовий дискурс щонайрізноманітніше репрезентує спектр згаданої проблематики. Дослідження питальних конструкцій у судовому дискурсі в українському мовознавстві наразі представлено не надто широко, здебільшого в окремих публікаціях Л. Пономарьової (Пономарьова, 2010а; Пономарьова, 2010в); Пономарьова, 2011), публікаціях і дисертаційній праці А. Просяної (Просяна, 2016а; Просяна, 2016в; Просяна, 2017; Просяна, 2018). Л. Пономарьова вказує на різноаспектний характер досліджень у межах дискурсу, відмінність у поглядах на функції питальних конструкцій у мовленні прокурора, адвоката, судді. Відносна автономність галузей юридичної сфери дає змогу використовувати питання по-своєму, відповідно до вузькофахової специфіки, де вони «можуть вказувати як на перехід від однієї думки до іншої, що визначає подальший зміст, так і на загострення уваги на найбільш складному боці справи. Мовець ставить питання, активізує слухачів, долучає їх до обговорювання справи і, таким чином, зумовлює їхню реакцію, формує думку» (Пономарьова, 2010). В аналізі питальних речень дослідниця спирається на класифікацію А. Загнітка, який виокремлює власне-питальні, питально-стверджувальні, питально-заперечні, питально-риторичні, питально-спонукальні речення (Загнітко, 2009). За спостереженням дослідниці, найчастіше під час судового засідання та процесуальних дій використовують власне-питальні речення, що вимагають обов'язкової відповіді (Пономарьова, 2010). Вони актуалізуються комунікативними намірами прокурора або адвоката, а їх коректна постановка передбачає з'ясування різних обставин справи й встановлення істини в ній або навмисно їх утруднює. Менш уживаними є питально-заперечні речення, у яких заперечується висловлене в самому питанні, та питально-спонукальні речення, де простежується спонукання співрозмовника до певної дії (Пономарьова, 2010). Л. Пономарьова вказує на істотну «специфіку питань судово-процесуального 
дискурсу» - функціювання «уточнювальних або уточнювально-пояснювальних питальних речень, що найчастіше використовуються 3 метою привернення уваги на юридично значущі моменти перебігу слідства» (Пономарьова, 2010: 57). Ці речення не тільки наповнюють процесуальне русло в дискурсі, вони оптимізують його поняттєво-термінологічний апарат та розкривають експлікаційні засоби процесорики. Авторка підкреслює емотивну вагомість питальнориторичних конструкцій, їхню значущість у посиленні емоційного настрою та пафосності мовлення юриста, що $є$ загалом природніми для правової діяльності. Проте аналізовані дослідження не охоплюють усіх комунікативних проявів судової сфери. Комплексно комунікативну природу українського юридичного дискурсу, зокрема функціювання питальних конструкцій в аспекті мовленнєвої поведінки його учасників досліджено в дисертаційній праці А. Просяної (Просяна, 2018). Диференціація на комунікативні ролі, стратегії, тактики обумовлює системність дискурсу - регламентоване мовлення всіх суб'єктів взаємодії. Такий підхід дав змогу дослідниці простежити тенденцію до використання питальних речень усіма учасниками комунікативної взаємодії - суддею, адвокатом, прокурором, підсудним / обвинувачуваним, свідком. Однак до мовлення когось із указаних комунікантів питальні конструкції не мають строгої прив'язки. У деяких комунікативних ситуаціях поширені як уточнювальні, так і з'ясувальні питання (Просяна, 2018). Їх уживання зумовлене «прагненням мовців отримати потрібну в судовому засіданні інформацію», що оптимізує його перебіг. Змістовність мовленнєвої взаємодії в межах дискурсу забезпечують здебільшого уточнювальні питання. Значущі комунікативні ефекти цих речень досить багатоаспекті, оскільки «адресат, відповідаючи на уточнювальне питання, не тільки дає ствердну відповідь, а й розширює, пояснює, коментує іï і разом 3 цим свою позицію» (Просяна, 2018: 156). У певних комунікативних ситуаціях спостерігаємо інтерпретацію уточнювальних питань як з'ясувальних, «коли адресату недостатньо однозначної стислої відповіді, він подає розгорнуту репліку» (Просяна, 2018: 156). Такі конструкції $€$ найпродуктивнішими для питально-відповідних комплексів судово-процесуального дискурсу.

Комунікативний простір у військовій сфері також достатньо регламентований. Професійно значущим у цьому дискурсі 
$€$ дотримання правил, що полягають в характері структурованої за різними аспектами інформації: способом кодування, розгортання; механізмом передавання, прийому й обробки; оптимізації діяльності всіх функційних елементів; параметрами нагляду, контролю. Комунікативний потенціал питальних конструкцій у військовому дискурсі на прикладі діалогу-радіообміну розглянуто у праці О. Шаблія. Якщо в діалозі вживають здебільшого питальні речення, то в діалозі-радіообміні, окрім питальних, використовують ще й спонукальні або імперативні (Шаблій, 2015). Результатом поєднань цих речень у межах діалогу-радіообміну є діалогічні єдності - сполучення осмисленої питально-відповідної взаємодії двох комунікантів. У процесі вибору варіантів мовленнєвої поведінки в діалозі сконструйовуються відповідні діалогічні єдності: розповідні (комбінація розповідного речення і репліки-відповіді), спонукальні (поєднання спонукального речення і відповідної репліки). Проте найчастіше в діалозі-радіообміні в діалогічну єдність входять питальні, спонукальні й розповідні речення (Шаблій, 2015). Специфікою діалогічних єдностей, чинником їхньої комунікативної ініціації є питання-ідентифікації: компонент “відповідь” не може бути однозначно витлумачений, якщо не поставлений компонент “питання”, оскільки відповіді без питання не існує. Важливим є об’єднання двох учасників. «Зайняті спільною діяльністю партнери обмінюються репліками на зразок: запит інформації - повідомлення інформації, повтор інформації, наказ - підтвердження наказу, повідомлення інформації - підтвердження отримання інформації (Шаблій, 2015: 130). У таких діалогах компонентом функційно спрямованих комунікативних дій є короткі речення, еліптичні конструкції, однослівні відповіді або питання.

\section{Висновки}

Для цілісного аналізу питальних речень, що слугують комунікативним знаряддям професійної діяльності, варто розрізняти питальні речення за типом запитання і передбачуваною відповіддю та за комунікативно-функційним спрямуванням: власне-питальні, фатичні та контактні, питально-спонукальні, констативні й риторичні речення, оптативні, авторизовано-оцінні. Оскільки професійне мовлення завжди підпорядковане спеціальній меті, ефективний аналіз питальних речень, що є його складниками, можливий лише за умови врахування 
структури відповідного дискурсу. Зокрема, у медичному дискурсі наявність автокомунікації лікаря зумовлює існування специфічної сфери функціювання питальних речень, що не спостерігаємо в мовленні інших фахівців. Для журналістської діяльності релевантним $є$ поділ на ситуацію інтерв'ю, де домінують власне-питальні речення, і монологічного викладу інформації в тексті публікації, де переважають невласне-питальні речення. В умовах судового засідання питання відіграють особливу регулювальну функцію, а їх аналіз має враховувати ритуальність відповідного дискурсу. Для військового радіомовлення характерна блокова структура, що впливає на роль питальних речень. Потребує всебічного дослідження використання питальних речень не тільки в згаданих професійних дискурсах, але й багатьох інших: педагогічному, у діяльності соціальних працівників, психологів, маркетологів, менеджерів тощо.

Грунтовне вивчення всіх аспектів функціювання питальних речень у професійній діяльності не тільки поглибить розуміння їхньої природи, а й сприятиме уточненню структури комунікативної та мовної компетенцій i, отже, уможливить ефективну мовну підготовку майбутніх фахівців.

\section{ЛІТЕРАТУРА}

1. Білодід, І. К. (Ред). (1969). Сучасна українська літературна мова. Синтаксис. Київ: Наук. думка. 2. Завальнюк, І. Я. (2009). Синтаксичні одиниці в мові украӥнської преси початку ХXI століття: функиіональний і прагмалінгвістичний аспекти. Вінниця: Нова книга. 3. Загнітко, А. (2009). Український синтаксис: теоретикоприкладний аспект. Донецьк: ДонНУ. 4. Івченко, М. П. (1965). Сучасна украйнська літературна мова. Київ: Вид-во Київ. ун-ту ім. Т. Г. Шевченка. 5. Карасик, В. И. (2002). Языковой круг: личность, концепты, дискурс. Волгоград: Перемена. 6. Литвиненко, Н. (А) (2009). Автокомунікація в медичному дискурсі (на матеріалі діалогів лікар - пацієнт). Українська мова, 3, 83-96. 7. Литвиненко, Н. (В) (2009). Український медичний дискурс. Харків: Харк. іст.-філол. т-во. 8. Панкова, М. (2007). Диференційні і класифікаційні ознаки українських питальних речень. Шевченківська весна. Матеріали Міжнар. наук.-практ. конф. студентів, аспірантів та молодих вчених (с. 109-113). Київ: ВЦ «Принт-центр». 9. Панкова, М. (2009а). Еволюція лінгвістичних поглядів на питальні речення: семантичний і комунікативний аспекти. Наук. пр. Чорном. держ. ун-ту ім. Петра Могили комплексу «Києво-Могилянська академія». Серія «Філологія. Мовознавство», 105 (92),102-106. 10. Панкова, М. (2009b). Еволюція поглядів на питальні речення: диференційний та класифікаційний аспекти. Лінгвістичні студіi, 19, 94-97. 11. Пономарьова, Л. В. (2010а). Комунікативні засоби вираження питання в судово-процесуальному дискурсі. Мова і Культура, 13, IX (145), 54-60. 12. Пономарьова, Л. (2011). Судова полеміка: мовленнєві прийоми, правила, помилки. 
Лінгвістичні студіï, 2, 187-191. 13. Пономарьова, Л. (2010b). Чинники ефективності мовленнєвої діяльності адвоката в судовому процесі. Мандрівець, 4, 72-75. 14. Просяна, А. В. (2018). Дослідження українського юридичного дискурсу: структурно-семантичний і лінгвопрагматичний аспекти. (Дис. ... канд. філол. наук). Одеса: Одес. нац. ун-т ім. I. І. Мечникова. 15. Просяна, А. В. (2016). Комунікативна поведінка учасників судового дискурсу: стратегії і тактики спілкування. Society for Cultural and Scientific Progress in Central and Eastern Europe Budapest. Science and Education a New Dimension. Philology, IV (23), Issue 100, 32-36. 16. Просяна, А. В. (2017). Лінгвопрагматика судового дискурсу: стратегії мовленнєвої поведінки комунікантів. Наук. пр. Кам'янець-Поділ. наи. ун-ту ім. Івана Огієнка: Філологічні науки, 44, 265-270. 17. Просяна, О. В. (2016). Український судовий дискурс: аспекти лінгвопрагматичного дослідження та сутнісні характеристики. Наук. вісн. Дрогоб. держ. пед. ун-ту ім. Івана Франка. Серія «Філологічні науки (мовознавство)», 6, 153-157. 18. Пономарів, О. Д. (Ред). (1997). Сучасна украӥнська мова. Київ: Либідь. 19. Центр розвитку кар'єри КПІ ім. Ігоря Сікорського. Дайджест актуальних вакансій (10.10.-16.10.). Узято з https:// rabota.kpi.ua/portfolio-items. 20. Шабат, С. Т. (2000). Категорія питальної модальності в сучасній українській мові. (Автореф. дис. ... канд. філол. наук). Івано-Франківськ: Прикарп. ун-т ім. Василя Стефаника. 21. Шабат, С. Т. (2001). Речення питальної модальності в сучасній українській мові. Мовознавство, 1, 53-58. 22. Шаблій, О. С. (2015). Особливості діалогічного мовлення курсантів вищих військових навчальних закладів. Вісн. Київ. наи. лінгв. ун-ту. Серія «Педагогіка та психологія», 24, 127-135. DOI: https://doi.10.32589/2412-9283.24.2015.69615.

\section{REFERENCES}

1. Bilodid, I. K. (Ed.). (1972). Suchasna ukrainska literaturna mova. Syntaksys [Modern Ukrainian literary language. Syntax]. Kyiv: Nauk. dumka [in Ukrainian]. 2. Zavalniuk, I. Ya. (2009). Syntaksychni odynytsi v movi ukrainskoi presy pochatku XXI stolittia: funktsionalnyi i prahmalinhvistychnyi aspekty: monohrafiia [Syntactical Units in the Language of the Ukrainian Press of the Beginning of the XXI c: Structure and Pragmastylistic Functions]. Vinnytsia: Nova knyha [in Ukrainian]. 3. Zagnitko, A. (2009). Ukrainskyi syntaksys: teoretykoprykladnyi aspekt [Ukrainian Syntax: Theoretical and Applied Aspect]. Donetsk: DonNU [in Ukranian]. 4. Ivchenko M. P. (1965). Suchasna ukrainska literaturna mova [Modern Ukrainian literary language]. Kyiv: Vyd-vo Kyiv. un-tu im. T. H. Shevchenka [in Ukrainian]. 5. Karasik, V. I. (2002). Yazykovoj krug: lichnost', koncepty, diskurs: monografiya [Language circle: personality, concepts, discourse]. Volgograd: Peremena [in Russian]. 6. Lytvynenko, N. (2009a). Avtokomunikatsiya v medychnomu dyskursi (na materiali dialohiv likar - patsiyent) [Autocommunication in the medical discourse (on the material of the dial-up doctor patient)]. Ukrainska mova - Ukrainian language, 3, 83-96 [in Ukrainian]. 7. Lytvynenko, N. (2009b). Ukrainskyi medychnyi dyskurs: monohrafiia [Modern Ukrainian medical discourse]. Kharkiv: Kharkivske istoryko-filolohichne tovarystvo [in Ukrainian]. 8. Pankova, M. (2007). Dyferentsiini i klasyfikatsiini oznaky ukrainskykh pytalnykh rechen [Differential and classification features of Ukrainian interrogative sentences]. Shevchenkivska vesna. Materialy Mizhnar. nauk.-prakt. konf. studentiv, aspirantiv ta molodykh vchenykh - Shevchenko spring. The proceedings of the International Interdisciplinary Scientific Conference of Students and young scientists named (pp. 109-113). Kyiv: VTs «Prynt-tsentr» [in Ukrainian]. 
9. Pankova, M. (A) (2009). Evoliutsiia linhvistychnykh pohliadiv na pytalni rechennia: semantychnyi i komunikatyvnyi aspekty [The Evolution of linguistic views of interrogative sentence, semantic and communicative aspects]. Nauk. pr. Chornom. derzh. un-tu im. Petra Mohyly kompleksu «Kyievo-Mohylianska akademiia». Seriia «Filolohiia. Movoznavstvo» Scientific works of the Petro Mohyla Black Sea State University of the Kyiv-Mohyla Academy complex. Series «Philology. Linguistics», 105 (92), 102-106 [in Ukrainian]. 10. Pankova, M. (2009b). Evoliutsiia pohliadiv na pytalni rechennia: dyferentsiinyi ta klasyfikatsiinyi aspekty [Evolution of views on interrogative sentences: differential and classification aspects]. Linhvistychni studii - Linguistic studies, 19, 94-97 [in Ukrainian]. 11. Ponomarova, L. V. (2010a). Komunikatyvni zasoby vyrazhennia pytannia v sudovo-protsesualnomu dyskursi [Communicative means of expressing the issue in the judicial discourse]. Mova i Kultura Language and Culture, 13, IX (145), 54-60 [in Ukrainian]. 12. Ponomarova, L. (2011). Sudova polemika: movlennievi pryiomy, pravyla, pomylky [Judicial controversy: speech techniques, rules, mistakes]. Linhvistychni studii - Linguistic studies, 2, 187-191 [in Ukrainian]. 13. Ponomarova, L. (B) (2010). Chynnyky efektyvnosti movlennievoi diialnosti advokata $\mathrm{v}$ sudovomu protsesi [Factors in the effectiveness of a lawyer's speech activity in court]. Mandrivets - The Traveler, 4, $72-75$ [in Ukrainian]. 14. Prosiana, A. V. (2018). Doslidzhennia ukrainskoho yurydychnoho dyskursu: strukturno-semantychnyi i linhvoprahmatychnyi aspekty [Research in Ukrainian legal discourse: structural-semantic and linguo-pragmatics aspects]. Candidate's thesis. Odesa: Odes. nats. un-t im. I. I. Mechnykova [in Ukrainian]. 15. Prosiana, A. V. (2016). Komunikatyvna povedinka uchasnykiv sudovoho dyskursu: stratehii i taktyky spilkuvannia [Communicative behavior of the participants of judicial discourse, communication strategies and tactics]. Society for Cultural and Scientific Progress in Central and Eastern Europe Budapest. Science and Education a New Dimension. Philology, IV (23), Issue 100, 32-36 [in Ukrainian]. 16. Prosiana, A. V. (2017). Linhvoprahmatyka sudovoho dyskursu: stratehii movlennievoi povedinky komunikantiv [Linguopragmatics of judicial discourse: strategies of speech behavior of communicants]. Nauk. pr. Kamianets-Podil. nats. un-tu im. Ivana Ohiienka: Filolohichni nauky - Scientific papers of Kamianets-Podilsky Ivan Ohiyenko National University: Philological Sciences, 44, 265-270 [in Ukrainian]. 17. Prosiana, O. V. (2016). Ukrainskyi sudovyi dyskurs: aspekty linhvoprahmatychnoho doslidzhennia ta sutnisni kharakterystyky [Ukrainian judicial discourse: aspects of lingual-pragmatic research and intrinsic characteristics]. Nauk. visn. Drohob. derzh. ped. un-tu im. Ivana Franka. Seriia «Filolohichni nauky (movoznavstvo)»-Scientific bulletin of the Ivan Franko Drohobych State Pedagogical University. Series «Philological Sciences (linguistics)», 6, 153-157 [in Ukrainian]. 18. Ponomariv, O. D. (Ed.). (1997). Suchasna ukrainska mova [Modern Ukrainian language]. Kyiv: Lybid [in Ukrainian]. 19. Tsentr rozvytku kariery KPI im. Ihoria Sikorskoho. Daidzhest aktualnykh vakansii (10.10.-16.10.) - Students Career and Recruitment Centre Igor Sikorsky Kyiv Polytechnic Institute. Digest of current vacancies. Retrieved from https://rabota.kpi.ua/portfolio-items [in Ukrainian]. 20. Shabat, S. T. (2000). Katehoriia pytalnoi modalnosti v suchasnii ukrainskii movi [The category of interrogative modality in the modern Ukrainian language]. Extended abstract of candidate's thesis. Ivano-Frankivsk: Prykarp. un-t im. Vasylia Stefanyka [in Ukrainian]. 21. Shabat, S. T. (2001). Rechennia pytalnoi modalnosti v suchasnii ukrainskii movi [Sentence of interrogative modality in modern Ukrainian language]. Movoznavstvo - Linguistics, 1, 53-58 [in Ukrainian]. 22. Shablii, O. S. (2015). Osoblyvosti dialohichnoho movlennia 
kursantiv vyshchykh viiskovykh navchalnykh zakladiv [Military Institute of Telecommunications and Informatization Cadets' dialogic speech features at higher military educational establishments]. Visn. Kyiv. nats. linhv. un-tu. Seriia «Pedahohika ta psykholohiia»-Bulletin of the Kyiv National Linguistic University. Series «Psychology and Pedagogy», 24, 127-135. DOI: https://doi.10.32589/2412-9283.24.2015.69615 [in Ukrainian].

Кривенко Сергій Миколайовии - кандидат філологічних наук, доцент, доцент кафедри української мови, літератури та культури, Національний технічний університет України «Київський політехнічний інститут імені Ігоря Сікорського»; проспект Перемоги, 37, Київ, 03056, Україна.

Тел.: +38-097-342-70-09

E-mail: kryvenkosergi@gmail.com

http://orcid.org/0000-0001-5497-1927

Kryvenko Serhii Mykolaiovych - Candidate of Philological Sciences (Ph.D.), Docent, Associate Professor at the Department of Ukrainian Language, Literature and Culture, National Technical University of Ukraine «Ihor Sikorskyi Kyiv Polytechnic Institute»; 37 Peremohy Av., Kyiv, 03056, Ukraine.

Надійшла до редакції 8 березня 2021 року

\section{CITATION}

ДСТУ 8302:2015: Кривенко С. М. Теоретичні засади вивчення питальних речень у контексті професійної діяльності. Лінгвістичні дослідження: зб. наук. пр. Харк. нац. пед. ун-ту імені Г. С. Сковороди. Харків, 2021. Вип. 54. Ч. I. С. 25-37. DOI: https:// doi.org/10.34142/23127546.2021.54.1.03

APA: Кривенко, С. М. (2021). Теоретичні засади вивчення питальних речень у контексті професійної діяльності. Лінгвістичні дослідження, 54 (I), 25-37. DOI: https://doi.org/10.34142/23127546.2021.54.1.03 